\title{
František Šmahel, Alma mater Pragensis. Studie k počátkům Univerzity Karlovy
}

Praha, Nakladatelství Karolinum 2016, 614 stran, ISBN 978-80-246-3203-2 + 978-80-246-3239-1

Profesor František Šmahel patř́ k největším znalcům nejstarších dějin pražské univerzity, což prokázal mnohokrát jak monografickými pracemi, tak početnou řadou studií v domácích i zahraničních publikacích, výstavních katalozích a odborných periodicích. Nyní došlo ke shrnutí jejich reprezentativního výběru v publikaci, s níž přišlo univerzitní nakladatelství Karolinum.

Soubor třiadvaceti studií F. Šmahela k dějinám pražské univerzity v prvních staletích její existence tvoří tři tematické okruhy: Pražské obecné učení v době lucemburské (studie I-IX), Fakulta svobodných umění do počátků husitství (studie X-XVI) a Utrakvistická univerzita (studie XVII-XXIII).

První oddíl knihy (Lucemburská univerzita) má těžiště ve dvou velkých tématech, jimiž jsou samotné počátky pražské univerzity a události okolo Dekretu kutnohorského z roku 1409. Ve druhé části autor shromáždil studie, týkající se artistické fakulty, které věnoval podstatnou část svého badatelského zájmu pracemi biografického rázu (např. o Jeronýmovi Pražském nebo Janu Husovi) a o podobě výuky na fakultě (disputace, kvodlibety). Závěrečný oddíl knihy je pak věnován dvěma staletím kališnické univerzity.

Ve všech statích se Šmahel projevuje jako mistrný znalec a interpret dobových pramenů, otvírající nová témata, která se ukázala zásadní pro další bádání a často přinášející nová metodologická řešení letitých problémů naší historiografie. Šmahel díky tomu, že se už v začátcích své odborné dráhy dostal do okruhu spoluautorů nového zpracování pražských univerzitních dějin (F. Kavka a kol., Stručné dějiny University Karlovy, 1964), mohl využít možnosti spolupráce se staršími kolegy, zapojení do mezinárodního výzkumu a v neposlední řadě i publikační př́ležitosti, které téma a jeho zpracování nabízelo. Již prvními pracemi o univerzitním studentstvu naznačil budoucí trend bádání, který směřoval k novému pojetí „sociálních a intelektuálních dějin“, ke komplexnímu poznání dané problematiky a jejímu začlenění do celospolečenského kontextu, což znamenalo nejen studium geografického a sociálního složení pražského studentstva, jeho mobility, ale i zevrubné zkoumání „curricula“ pražského středověkého studenta. Šmahelovi patř́ také zásluha, že rozpoznal, že pražská univerzita přes všechny převratné změny, které přineslo husitství, žila stále ve stínu původního středověkého karlovského učení (a jeho struktury) až do počátků 17. století. Vedle tohoto hlavního badatelského zájmu pak vznikly studie o knihovnách univerzitních kolejí, o jejich katalozích a práce o počátcích humanismu na pražské univerzitní půdě.

Těžko vyzdvihnout metodologický př́nos a badatelské výsledky jednotlivých studií - byl by to dlouhý výčet, který by vlastně stavěl recenzenta před „nelidský úkol“: shrnout v několika řádcích celoživotní badatelské úsilí. Pokusme se alespoň skicovat, co nového a podnětného Šmahel přináší k jednotlivým tématům. Detailní poznání počátků pražské univerzity má pro něho svůj význam nejen proto, že šlo o první domácí univerzitu a první vysokou školu střední Evropy, ale i pro „,vyzařování“ (autorův výraz) jejího vzoru do okolních zemí. Klíč k jejímu pochopení hledá Šmahel v univerzitních statutech, které určily charakteristické rysy pražského učení: její „rozdvojeni'“ na tř́fakultní a juristickou univerzitu, dominanci 
artistické fakulty a význam kolejí pro celkovou podobu školy, pro výuku i všední život pražské středověké univerzity.

Badatelské postupy (znalost pramenů, včetně těch, které byly do té doby považovány za druhořadé, kombinace biografických a institucionálních dějin a znalost dobového kontextu, mám-li uvést alespoň ty nejvýznamnější) ukázal Šmahel na zpracování dějin předhusitské lékařské fakulty, o níž se mělo za to, že patř́ k nejméně dokumentovaným částem pražského středověkého učení. Vyrovnání se s jedním z klíčových témat pražské univerzity (Dekret kutnohorský), původně určené zahraniční odborné veřejnosti, bylo doplněno bilanční studií k výročí Václavova mandátu v roce 2009 (spolu s M. Nodlem). Užitím nové a náročné prosopografické metody pak Šmahel jasně prokázal, že dř́ve čistě „nacionalisticky či mocensky“ chápaný spor o dominanci na pražské univerzitě byl sociální záležitostí mnohovrstevnaté povahy (teologické, ,vnitrouniverzitní“ a politické).

Druhá část publikace je věnována fakultě svobodných umění $\mathrm{v}$ předhusitském období. V ní autor ukázal druhou silnou stránku svého badatelského př́stupu, když spojil minuciózní analýzu dílčích aspektů fakultního života se syntetizujícím výkladem o klíčové fakultě pražské středověké univerzity. Navíc, toto téma bylo pro autora příležitostí, aby ukázal „každodenní život“ pražské univerzity, především skutečnou podobu fakultní výuky, kterou srovnává se statutárními předpisy. Rozborem doktrinálních sporů na akademické půdě v předhusitském období pak poukázal na význam univerzitních disputací (kvodlibetů) pro formování reformních názorů ve společnosti a na úlohu univerzitánů při jejich šíření.

Třetí oddíl přináší Šmahelovy vrcholné texty, týkající se pražské univerzity. To, jak dokázal vytěžit např. materiál shromážděný v Rukověti humanistického básnictví, bylo originální a př́nosné nejen v době svého vzniku (v letech 1982 až 1984), ale udržuje si dodnes punc „,novosti““ a vysokého standardu.

Hledám-li (těžko) slabinu Šmahelova výkladu nejstarších pražských univerzitních dějin, spatřoval bych ji v jistém ,upozadění“ evropských vzorů pro Prahu. Není přece sporu o tom, že univerzita byla celoevropským fenoménem a Praha (i se svými zvláštnostmi) je věrnou nápodobou obou velkých univerzitních vzorů (Pařǐže a Boloně), které měly po mém soudu větší význam pro podobu univerzity i pro její každodenní život, než je jim přisuzováno (a dodejme: je obrovskou zásluhou „otců zakladatelư“, Karla IV. i Arnošta z Pardubic, že přenesli tento evropský koncept a jeho vzory bez velkých změn do Prahy). Jen těžko se také mohu vyrovnat s označením studentů a absolventů pražské univerzity období 1433 až 1622 za humanisty. I když bych bral v úvahu pouze předbělohorské /půl/století a veškeré změny ve složení profesorského sboru, $\mathrm{v}$ jeho profesních zájmech a v univerzitní výuce, těžko mluvit o humanistech, jak je známe z ostatních evropských zemí, nemáme-li ovšem na mysli onen zvláštní druh našeho „literárního humanismu“, jehož dominantním znakem bylo latinské veršování podle klasických vzorů a úloha školy, včetně univerzity, při jejich zprostředkování.

Shrnu-li, mohu konstatovat, že cena posuzovaného souboru studií prof. Františka Šmahela spočívá nejen v soustředění statí rozesetých po desítkách mnohdy jen obtížně dostupných publikací a ve zpř́stupnění cizojazyčných prací nyní v autorově mateřštině a v tematizovaném přehledu běžného chronologického výkladu, dávajícího navíc šanci vedle soustředěného přehledu badatelských výsledků proniknutí do „autorovy tvưrčí dílny s postupem času“ a zprostředkování geneze jeho názorů. Soubor Šmahelových odborných studií má po mém soudu význam přinejmenším dvojí: čtenáři přináší poučený moderní výklad o prvotní 
fázi pražských univerzitních dějin a zájemci o hlubší poznání minulosti pražské univerzity pak podává přehled základních a klíčových problémových okruhů její podoby v nejstarším období. V obou směrech se dostává čtenáři do ruky špičkový výkon českého dějepisectví posledního padesátiletí, který bude, troufám si tvrdit, v dohledné době jen stěží překonán.

doi: $10.14712 / 23365730.2018 .43$

\section{Elisabeth Tuisl, Die Medizinische Fakultät der Universität Wien im Mittelalter. Von der Gründung der Universität 1365 bis zum Tod Kaiser Maximilians I. 1519 \\ V\&R unipress, Vienna University Press, Göttingen 2014, 366 s., 13 čb vyobrazení, ISBN 978-3-8471-0330-1 a 978-3-8470-0330-4 (e-book)}

K sepsání zprávy o knize uvedené v titulu přistupuji s jistými rozpaky jednak proto, že publikace je již tři roky stará, a jednak proto, že se jedná o dílo chronologicky zapadající do období, kterému se nevěnuji. Jedná se však o počin zcela mimořádného významu pro dějiny univerzit ve střední Evropě a také pro dějiny medicíny, který by měl být na stránkách tohoto odborného časopisu zmíněn. Čtenářům HUCP zde tudíž předkládám pouhou zprávu s minimem hodnotících prvků a doufám, že se v budoucnosti někdo ujme důkladné recenze.

Jak název napovídá, máme před sebou monografii, jejímž základem byla diplomová práce Elisabethy Tuislové z roku 2008, kterou dále doplnilo důkladné studium ve vídeňském univerzitním archivu. Publikace má dvě hlavní části - historickou a prosopografickou.

Historická část je dále rozdělena do sedmi oddílů. První poskytuje obecný rámec k vlastnímu předmětu monografie a začíná stručným přehledem vývoje medicíny od antiky přes klášterní medicínu a arabské vlivy ve středověku až po popis vlny zakládání lékařských fakult na evropských univerzitách. Druhý oddíl se zabývá založením Vídeňské univerzity $\mathrm{v}$ roce 1365, poté na základě zachovaných statut podrobně rozebírá, co je známo o organizaci její lékařské fakulty. Ve třetím oddíle se dozvíme něco o historickém nemovitém majetku fakulty kolejemi počínaje přes špitál a knihovnou konče.

Následující oddíl, který je nesmírně zajímavý pro právě probíhající výzkum o dějinách vzdělanosti v Čechách, si klade otázku, jak probíhala výuka medicíny ve Vídni. Není to př́lišs známo, ale Vídeňská univerzita má patrně nejstarší tiskem vydaný přehled o přednáškách a obsahu studia v Evropě. Jedná se o Liber de modo studendi seu legendi in medicina profesora Martina Stainpeise z roku 1520. Tento text je zvláště cenný tím, že v celém 16. století vyšlo v Evropě jen několik podobných tisků a že zachycuje situaci na nám blízké Vídeňské univerzitě. V Čechách vznikla publikace s podobným obsahem (odhlédneme-li od krátké řeči na obhajobu výuky anatomie vydané na počátku 17. století Adamem Zalužanským ze Zalužan) až na samém konci 17. století díky Janu Františku Löwovi z Erlsfeldu.

Pátý oddíl představuje pokus o rekonstrukci chronologického vývoje dějin lékařské fakulty nejprve odděleně ve 14. století. Zde autorka akcentovala osobu Mistra Galeazza de Santa Sofia a také osoby spojující Vídeň s významnými evropskými fakultami. Na tomto místě je potřeba upozornit, že se jedná, s ohledem na sporé prameny, o velice stručnou 